Boise State University

ScholarWorks

Political Science Faculty Publications and

Presentations

Department of Political Science

3-24-2011

\title{
Primary Factors Influencing Green Building in Cities in the Pacific Northwest
}

Susan Mason

Boise State University

Tony Marker

Boise State University

Rebecca Mirsky

Boise State University 


\title{
Primary Factors Influencing Green Building in Cities in the Pacific Northwest
}

\author{
Susan G. Mason, Tony Marker, and Rebecca Mirsky \\ Boise State University
}

\begin{abstract}
This article provides empirical evidence that the factors of context and social climate are the most influential for achieving green building. Using both chi-squared analysis and factor analysis findings indicate that providing the context and social climate which can reduce transaction costs influence green building. Specifically, through policies and guidelines, having the local expertise and support to make the outcomes occur are all important factors. Additionally, central cities were much more likely to engage in green building than suburban or non-metropolitan areas. This finding has implications for matters of collective action.
\end{abstract}

Keywords: green building, climate change, city development

Despite the increasing awareness of the impacts of climate change, Greenhouse Gas (GHG) emissions continue to rise. National indicators reveal emissions climbed from 7,075 million metric tons of carbon dioxide equivalent (MTCDE) in 2000 to 7,282 million MTCDE in 2007. Energy consumption is the largest producer of carbon dioxide $\left(\mathrm{CO}_{2}\right)$ generating 5,917 million of the 7,282 million MTCDE in the U.S. in 2007. Nationally, energy consumption is broken down by sector with transportation generating the most GHG emissions (1,903 million MTCDE), followed by industry (1,655 million MTCDE), then residential buildings (1,261 million MTCDE) and commercial buildings (1,097 million MTCDE). Residential and commercial buildings combined account for $40 \%$ of all energy consumption and energy related GHG emissions annually in the U.S., exceeding that of the transportation sector (Energy Information Administration (EIA), 2009). Looking in detail at the average operating cost of commercial buildings in Los Angeles, California, energy consumption is the largest single category (31\%), followed by repairs and maintenance (24\%), then administration (18\%), and cleaning (17\%) (Chao et al., 1999, p. 11).

While financial savings associated with lower operating costs (such as energy usage) are important, the more significant long-term financial benefits of green building, and LEED certification in particular, are associated with improvements to employee productivity. "Salaries represent approximately $90 \%$ of the money flow through a building, the rest being amortized construction costs, operations and maintenance, including utilities" (Watson, 2008, p. 14).

Developers typically have less of a stake in how productive employees are after a building is completed unless the developer is also the end user, as well. For those developers who eventually sell the green buildings, this finding this suggests a potentially powerful marketing tool to help those developers recoup some of the up-front building costs. Smith (2003) reports:

An increase of 1 percent in productivity (measured by production rate, production quality, or absenteeism) can provide savings to a facility that exceeds its entire energy bill. It is easy to see why this is the case by comparing the relative operating costs for commercial business. On average, annualized costs for personnel amount to $\$ 200$ per square foot-compared with $\$ 20$ per square foot for bricks and mortar and \$2 per square foot for energy. A modest investment in soft features, such as access to pleasant views, increased daylight, fresh air, and personal environment controls, can quickly translate into significant bottom-line savings.

Lockwood looked at the costs of retrofits in a 2008 study. In his report, he asserts that a growing number of companies are implementing green retrofits of their buildings to save money, improve productivity, lower absenteeism and healthcare costs, strengthen employee attraction and retention, and improve their corporate 
sustainability reports and brand equity - all at a relatively modest cost. However, Lockwood goes on to suggest that timing is important for companies seeking to use green retrofits as a point of competitive differentiation.

If scientists are correct and global temperatures rise anywhere between 2.5 to 10 degrees Fahrenheit this century due to increased GHG emissions, then the potential value to cities and the construction industry in taking the lead to reduce the 1,097 million MTCDE generated by commercial buildings alone or the combined 2,358 million MTCDE for residential and commercial buildings could be vast. The climate changes anticipated due to large and increasing amounts of GHG emissions include more frequent floods, droughts and rising sea levels to name just a few.

Technologies and best practices for reducing GHG emission may be some of the best ways to mitigate the effects of climate change. Given "the average LEED certified building uses 32 percent less electricity and saves 350 metric tons of $\mathrm{CO}_{2}$ emissions annually" (United States Green building Council (USGBC), 2008 p. 2) green buildings may go a long way to fight climate change. If just half of all commercial buildings used 50 percent less energy in their 50 to 100 year lifetime, then the reduction of GHG emissions would be the equivalent of taking more than 1 million cars off the road or reducing $\mathrm{CO}_{2}$ emissions by 6 million metric tons annually (USGBC, 2008).

Communities are rising to the challenge. As of April 2010, over 1,000 U.S. city mayors committed to reducing GHG emissions by seven percent or more by 2012, to reduce pollution below the levels of 1990 (United States Conference of Mayors Climate Protection Center, 2009). The Mayors Agreement signees agreed to urge federal and state governments to create policies that ensure meeting reduction goals by 2012, and pledged to make strides in their communities as well. The conventional wisdom among planners for achieving reductions in GHG emissions through the construction of more green buildings is to employ some or all of the three techniques in the planner's arsenal: reduce barriers, create incentives, and/or regulate (Duerksen 2009; Interviews, 2009). Yet cities have limited resources to deploy to maximize goals such as increasing green building to reduce GHG emissions in their communities. Knowing which factors will have the biggest impact helps cities use their resources judiciously.

To address this concern, this research examines the factors of context, social climate, political factors, capacity, and instrumentation by comparing survey data for cities with and with out LEED registered and certified buildings. This allows us to look for patterns. Additional exploratory factor analysis is pursued to understand more about the influences of the various factors. There are many factors that can influence outcomes in cities. Many studies have focused on the positional factors such as clustering or transaction costs (Jacobs 1968; Porter 1990; and Dawkins, 2000) or compositional factors such as location or industry (Lewis, 2001; and Zaharan et al, 2008). Political factors such as the influence of elites and urban regimes (Basolo 2000; Stone 1989), social issues of equity in sustainable planning (Saha \& Paterson, 2008 ), capacity to implement plans (Jepson, 2004), and instrumentation or the tools in terms of taxes and subsidies (Sullivan, 2002; Feiock \& Stream, 2001; and Eisinger, 1988) have also been considered. Feiock and Stream (2001) also looked at multiple economic incentives and factors that might influence environmental policy design. Similarly this study casts a broad net, bringing these separate bodies of knowledge together to gain a greater understanding of the factors that, at the city level, facilitate LEED registered or certified green buildings in particular, and green building in general. The primary research questions are:

- Is there a pattern of practices for cities that engage in green building which differs from cities that do not have LEED registered or certified buildings?

- When considering context, social climate, political, capacity and economic factors, which factors are the strongest among the categories for generating green buildings?

- Within the categories of context, social climate, political, capacity, and economic influences, which specific tools are most influential in generating green buildings?

This study sorts out the most salient combination of factors for encouraging the construction of LEED registered or certified buildings. This information provides a roadmap to understand which combination of tools will be most advantageous for cities that wish to promote green building in their planning practices to help meet their goals of reducing GHG emissions by mitigating buildings' effects on climate change. This study finds across two types of analysis that context and social climate are two current methods that do indeed positively impact the adoption of green building. City capacity is also important, but somewhat less so. Although surveys revealed insufficient evidence to gauge the effectiveness of political factors and economic tools, factor analysis is suggestive that at least political factors could be formidable incentives if employed. 
The article begins with a review of the literature on context; social climate; political factors; capacity; and instrumentation (i.e. economic tools). There is an emphasis on quantitative studies from the fields of economic development and planning. Then the procedures and methods used in the study are discussed before turning to an analysis of the results. The article concludes with a consideration of the policy implications, most promising planning practices, and directions for further research.

\section{Drivers of Decisions: Competing Explanations and Empirical Studies}

Individuals and cities both assume risk and uncertainty, and weigh the options, gains and outcomes in promoting development especially when engaging in entrepreneurial behavior such as green building. When there are few examples or models to assess prior to engaging in green building, it is difficult to gauge the risk or uncertainty of the return on the investment. This is the case for both members of the construction industry and cities. There are several factors that play into the perceived level of risk that both cities and individuals must consider. This highlights the need to bring together a wider literature on the discussion of construction industry members' willingness to engage in green building. The discussion draws broadly from five primary factors that scholars have identified as relevant to assessing risk or outcomes: context; social climate; political factors; capacity; and instrumentation.

\section{Context: Positional and Compositional Factors}

The positional and compositional factors for an individual are derived from state as well as local factors that can be related to geography and influence the proclivity of green building. Positional factors refer to a city's position or stance on a policy. At the state level there may be regulations that require energy use reduction, or state guidance on green building that affects a city's position on green building. At the local level, has the Mayor signed on to a climate protection program signaling a commitment to this type of development? At the individual level, positional information can give a construction industry member a sense of certainty about the value and ongoing need for green building. All of these factors affect the transaction costs.

Dawkins (2000) points out that rational decision makers seek to optimize social benefits provided the property rights are clearly defined and enforcing agreements are free. Transaction costs exist, which may include legal and administrative costs for dealing with contracts and agreements. One example might be that a building needs to meet certain standards or criteria in terms of water conservation or energy use to qualify as a green building. It is for this reason that policy makers must decide how to intervene rather than when to intervene (Dawkins, 2000, p. 508). In land use policy planning Dawkins notes that there are two types of asset specificity that are relevant. One is site specificity, such as transportation costs, which is tied to the location. The other is temporal asset specificity. Temporal assets are bound by the past and future transactions. In construction, "land investments are highly durable and costly to demolish, landowners are bound by space and time to the investment decision of previous and future landowners" (Dawkins, 2000, p. 512).

One way cities can reduce the transaction costs of green building is to lay out the goals, standards, and expectations. Saha and Paterson (2008) demonstrated formal commitments such as having policies encouraging green building, dedicating staff to the issue, and incorporating sustainability into comprehensive plans to increase the likelihood of engaging in sustainable practices (pp. 28-30). Jepson also found "a significant statistical association...to exist between the communities' activity levels and the leadership character of the local planning offices...This indicates that it is possible for planners to stretch their roles in local government so as to be advocates and catalysts with respect to a wider range of issues than just those that are directly related to land use planning and regulation" (pp.236-237). Clear messages about the goals, standards and expectations allow the development of systems of interconnected firms to meet those expectations. Allen and Potiowsky's (2008) study provides evidence of this clustering outcome in their Portland area study where both the state of Oregon and city of Portland have actively promoted green building for the last several years (p. 304).

Compositional factors can be geographic such as being a central city which is more prone to look outward and base their decisions on a greater degree to regional considerations than do cities in suburbs. Both central cities and suburban cities are prone to looking inward with regard to the localized effects of decisions in land use policy (Lewis 2001, pp. 699, 717). Sullivan found local governments in nonmetropolitan or rural locations to be positively associated with risk taking to achieve economic development (Sullivan 2002, p. 124). 


\section{Social Climate}

Individuals, cities and states may have varying degrees of commitment to sustainability in general. The commitment can be formal and very public such as signing onto the Mayor's Climate Protection Agreement, meeting state regulations or engaging in green building for a density bonus. There are less formal but at times just as public of commitments that tap into the social desirability of engaging in sustainable development behaviors. It may be the championing of green building by respected individual developers and architects with a personal passion, or local elected officials touting praise for such endeavors, and state level recognition of prominent buildings or other endeavors that craft the social climate or desirability of green building. Social aspects in terms of public and private levels of commitment to sustainability do play a role in generating a social climate as Saha and Paterson (2008) found. Interviews and focus groups (2009) reveal that promotion and recognition by local leaders as well as individual developer champions help reduce risk and provide incentives to build green. One interviewee from a private firm in the State of Washington flatly noted that, "Cities are the future. Mayors are critical because it is really a local thing and important for the mayor and people to move it forward because that is where it happens. State and Federal government will not lead this." In contrast, a planning director in the state of Washington noted the leadership really needed to start at the very top, "Starts with leadership from the top and that will improve in next few years if the Feds put out the right signals and [the signals] get translated down. Europeans have done it and even Canadians have done it and we are still thinking about it. Energy generation and use is the next big thing. Green building gets at the center of it." A public sector interviewee in Oregon, where there are more incentives for green building than many states, notes, "Leadership that promotes green building is important. You need a Mayor type to say 'this is a priority'. Our Mayor elect is doing that here... one congressman came to speak too and since then it has moved it up [the river basin's] priorities. Political leadership to get on board is important and people need to see practices of green building." There is empirical evidence of the importance of leadership, as well, where Jepson (2004) found the number of times a planning office took a leadership position on sustainable issues was associated with the number of times action on sustainable development issues were taken ( p.235). In short, formal levels of commitment play a role in advancing sustainability goals, however the social climate may also influence green building outcomes.

\section{Political Factors}

Since land use policy planning as Dawkins (2000) notes entails both site specificity and temporal asset specificity then, when the implementation of land use policy instruments is not based on future land use plans the instruments are more likely to be adjusted to meet the changing demands of local political interests. Dawkins (2000) concludes this is appropriate because if these adjustments are not made it will increase the uncertainty for the construction industry members and in turn the transaction costs. In places without a strong commitment to a particular brand or plan then political factors may play a larger role in determining outcomes (p. 513). These political factors can include competition among cities (Peterson, 1981). There is evidence that adjacent cities compete for business using tax increment financing (Mason and Thomas, 2010). A testable idea and example of this is the political factor of proximity of other cities engaging in green building activities could either influence or detract from green building in city.

The power of local elites (Wildavsky, 1964) and even regime theory advocates that politics may play a key role in local decisions (Stone, 1986). If the power of local elites or regimes plays a role we might find that developers may threaten to take their development elsewhere to avoid new standards or alternatively attempt to encourage leaders not to adopt new standards. Exactly how local elites and regime theory might play out in provision of incentives or creation of barriers to green building has not been specifically been examined before.

Similar to this study Basolo (2000) considered both economic and political factors as potential decision drivers for cities. She found that political factors were actually more important than inner-city competition for explaining some policy choices (p. 329). This makes looking at both competition and role of local elites salient for this study. Knowing if the same factors hold up for climate change policies in general and green building in particular could be telling of these theories generalizability. As such this study examines the specific political factors of proximity; political pushback; and developer pushback. 


\section{Capacity to Implement Plans}

Jepson (2004) finds that planners with the motivation and education create capacity in the local planning offices to be more active in implementing sustainable initiatives. Specifically planners that take on leadership roles by providing "stronger arguments, stauncher advocates and more knowledgeable staff" provide the capacity for research analysis and education that make sustainable activities more likely (p. 236). Having the capacity at the local planning level is important. Saha and Paterson (2008, p. 34) aptly note several barriers to achieving sustainability in their survey research further reinforcing the value that such factors as funding, elected officials support, and knowledgeable staff can play in sustainability initiatives. In accordance Jeong and Feiock (2006, p. 757) find agencies with greater administrative capacity in and of themselves command more resources, both financial and in terms of staff to more effectively implement policies. Sullivan (2002, p. 121) also found bureaucratic capacity was the most important factor for predicting local government use of subsidy controls.

\section{Instrumentation: Economic Policy Tools}

Capacity to implement plans also entails the more formal tools or "instrumentation" to implement sustainable activities. These other capacity factors include having the resources to implement ideas as noted previously and also the backing in terms of state mandates or required uses of funding such as city utility funds.

The tools used that deter or foster green building are more or less the same tools for economic policy in general. These tools are well documented in the scholarship and include specifics such as incentives, tax credits, and regulatory certainty that decreases risk for both the city and developer (Sullivan, 2002, p. 117). Four general categories of instruments are derived from Linder and Peters (1989) and McGuire (2000) for this research: Promotion; Subsidy; Direct Provision; and Contracting. Table 1 displays the tools addressed in this research by their categories. Each of the four primary factors in Table $1 \mathrm{can}$ and have been analyzed in great detail in terms of their influence on policy outcomes by other scholars. This research focuses on the combination of context, social climate, political, capacity and instrumentation factors that influence green building to understand when and where which polices will be most influential.

\section{[Insert Table 1 about here]}

\section{Research Design}

Three questions are addressed in this research:

1) Is there a pattern of practices for cities that engage in green building which differs from cities that do not have LEED registered or certified buildings? If the former is true, those factors may point to best practices. If not, what else might explain the differences?

2) Of the factors on context, social, political, capacity and economic tools identified in the literature which are most salient in resulting in LEED registered or certified buildings?

3) Within the categories of context, social, political, capacity and economic influences, which specific tools are most influential in generating green buildings?

\section{Data Collection and Methodology}

The survey was developed after several interviews with planning directors in Oregon and Washington, and after having conducted focus groups in Idaho that included local planners and public works personnel and separate focus groups with developers, construction industry members and architects. The city planner survey questions were also modeled from surveys previously used by Saha and Paterson (2008) and Jepson (2004) and were pre-tested with selected interviewees for clarity. The final survey was sent to planning directors in all cities with a population of 2,500 or more in Idaho, Oregon, Utah, and Washington. A reminder letter with a paper copy of the survey was mailed approximately three weeks later. Planning directors were also contacted by phone to encourage survey responses. The overall response rate was 51 percent with 201 of the 396 cities responding to the survey. Using Chisquare which allows for comparison in responses between two groups the research can ascertain if there are patterns 
in factors that contribute to the outcomes for cities with and without LEED registered buildings. The additional use of factor analysis permits the exploration of the factors, in an atheoretical fashion, which may be having the greatest influence on the outcomes found in this study.

\section{Measures}

\section{Dependent Variables}

Data for the dependent variable, the number of LEED registered or certified buildings, was provided by the USGBC as of June 3, 2009. This data does not reflect all green building but is at a minimum one measure of green building activity that is universally recognized as meeting a green building standard. Additionally, the data are readily available for cities and states across the country for comparison. It includes information on:

- Buildings registered for LEED certification at one of the four certification levels - certified, silver, gold, or platinum

- Buildings listed as confidential listings in the dataset, which therefore cannot be matched to a city

- LEED registered and certified buildings in cities or unincorporated locations that have populations of fewer than 2,500

The final number of LEED registered or certified buildings used in this analysis reflect the data for buildings linked to a city with a population 2,500 or more. This data identifies 1,117 buildings across 164 different cities in the four states included in this study. There are numerous registered or certified buildings across many cities in each of the four states. Washington has the highest percentage of cities with LEED registered or certified buildings at 52 percent, while Utah has the lowest at 31 percent. However most cities had just a few buildings with 232 of the 396 cities not having any LEED registered or certified buildings. Of the remaining 164 cities, 89 percent had fewer than ten LEED registered or certified buildings.

\section{Independent Variables}

The independent variables included support from elected officials as evidenced by the response on the survey to the question, "Does your city Mayor support green building practices?" Respondents indicated on a five point scale the level of support the mayor has for green building ranging from "does not support" to "supports". Data also included whether the mayor had signed the U.S. Conference of Mayor's Climate Protection Agreement. Variables indicating whether the city had established green building as a goal or had created policies governing green building were also included. Political factors such as competition between cities for development and developer pushback were explored. On these questions respondents indicated how important these factors are in terms of actually influencing policy on green building in their city, using the scale five point scale ranging from no "influence" to "very strong influence". Although no evidence currently exists to suggest cities use green buildings to compete with each other, this study considers whether cities either compete or seek to avoid green building to maintain a particular status within their metropolitan area. Finally, resources such as number of personnel working for public works and planning departments, and staff that are LEED accredited, or personnel specifically responsible for green building projects were considered. Variables for city typology as city, suburban, or non-metropolitan were also included. A host of economic tools were also considered for each category of instrumentation. See Table 2 for a list of all the variables broken down by type (i.e. context, social climate, political, capacity and instrumentation).

\section{[Insert Table 2 about here]}

\section{Controls}

Although it is not the focus of this article, studies have identified other potential determinants of development and some of these have been incorporated as control variables in this analysis. The cities' population, educational attainment, median income, population growth and poverty (Sullivan 2002; and Lewis, 2001) are also considered. Specifically, increased population, population change, median household income, and education have a positive 
influence on development. Sullivan also found population to be positively associated with risk taking to achieve economic development and that population size was positively associated with administrative capacity.

\section{Analysis of Cities with and without LEED Buildings}

To address the first research question of whether there is a pattern of practices for cities that do and do not have LEED registered or certified buildings, an analysis is performed of the survey data comparing cities with LEED buildings to those without. However, before launching into the analysis, it is necessary to get a sense of the population of city respondents that did respond versus the ones that did not respond to the survey.

\section{Respondents}

A comparison of cities that responded to the survey with cities that did not reveals some trends as seen in Table 3. On average, larger cities with less population change, higher median household incomes, and lower poverty rates were more likely to respond to the survey. However, additional analysis revealed no statistical differences between the cities that responded, and the cities that did not respond to the survey by population, population growth, income or poverty. In the case of education, there was a statistically significant difference where cities with a greater percent of persons with a bachelor's degree responded more frequently to the survey. Self selection bias is prevalent in survey research where the wealthier and more highly educated tend to respond more often (Fowler, 1993). This was found to be the case for education at the city level in this study.

\section{[Insert Table 3 about here]}

\section{Findings}

\section{Context Factors}

Cities whose mayors have signed the U.S. Conference for Mayors Climate Change Protection Agreement were more likely to have LEED buildings (86\%) compared to cities whose mayors have not signed the agreement (35\%) as seen in Table 4. Additionally, there was an association between having green buildings as a goal or priority for a city and having LEED registered or certified buildings. This holds true whether the goal was formal and written or informal and unwritten (See Table 5). The same was true for having a policy and guidelines (See Table 6). Clearly establishing green building as a priority and even providing formal guidance was much more frequently associated with a city having green buildings than not. This suggests that a city for which green building is a priority can see a difference in the outcomes. There was no statistically significant difference among cities with and without state policies in terms on whether or not they had LEED registered or certified buildings, even though all the states in the study besides Idaho have state policies on green building.

\section{[Insert Tables 4, 5, and 6 about here]}

There was a statistically significant association with regard to how cities noted the influence of federal policy and having green buildings. Differences were greatest for cities without LEED buildings noting that federal guidance either had no influence $(68 \%)$ or very strong influence $(71 \%)$ on outcomes. That is to say the outcomes were bimodal with the strongest associations for cities without LEED registered or certified buildings at either extreme as seen in Table 7 as compared to cities with LEED buildings. There was not a statistical relationship between the reported influence of state guidance and LEED registered or certified buildings. Nor was there an association with the perception that the International Code Council or other drafting body having an influence on green building. There was a statically significant association as seen in Table 8 between the perception of influence of the Cities for Climate Protection Mayor's agreement and having green buildings; but again, cities that did not have LEED buildings demonstrated a bi-modal split in their responses with many non LEED building cities indicating they believed it had moderate influence (63\%) or no influence (63\%) as compared to responses from cities with LEED buildings. Perhaps more notable though is that 32 percent of cities with LEED buildings indicated having signed the agreement would influence having more green building. 
Finally, being a core city $^{1}$, suburban city or nonmetropolitan city was associated with having LEED buildings where core cities had a much greater propensity than suburban and nonmetropolitan cities. Suburban cities were slightly more likely to have green buildings than nonmetropolitan cities as seen in Table 9.

[Insert Tables 7, 8, and 9 about here]

\section{Social Climate}

When comparing cities that do and do not have LEED registered or certified buildings, the survey data indicates that there was no statistical differences in cities having or not having green buildings based on reported mayoral support for green buildings. Tables 10 and 11 reveal that having a developer or architect that is familiar with and promotes green building relates to a greater likelihood of having LEED registered or certified buildings or other formally recognized green buildings (e.g. Energy Star rated) in the city. This suggests these social climate factors aid in promoting green building in a community.

\section{[Insert Table 10 and 11 about here]}

\section{[Insert Table 12 about here]}

\section{Political}

The reported influence of neighboring cities either engaging in green building or not was not associated with having LEED buildings. In contrast to what respondents indicated chi-squared analysis revealed that a city being adjacent to another city with LEED buildings was associated with having LEED buildings as seem in Table 13. Adjacency was determined using GIS as compared to self-reporting on the survey. The relationship was positive and significant with a crammer's V of .57. After controlling for the effect of being a central city or not, non-central cities showed a statistically significant and positive association with having LEED buildings if adjacent to another city with LEED buildings. This contrast between perception and reality will be discussed in the conclusions. There was no difference for central cities with regard to having LEED buildings or not if they were adjacent to a city with LEED buildings and actually 25 of the 27 central cities did have LEED buildings. The respondents' response on the reported influence of developer and political pushback was not associated with a city having green buildings or not.

\section{[Insert Table 13 about here]}

\section{Capacity}

Cities with a dedicated office or personnel responsible for green building-as well as more public works personnel and planners, staff, and persons accredited as LEED AP-were all associated with having more green buildings. This suggests the importance of having more resources and expertise being associated with having LEED buildings. As larger cities are more likely to have more staff, this may be a function of city size (as Sullivan found) meaning that larger cities simply have more capacity. We examine this supposition next.

\section{[Insert Tables 14-17 about here]}

Table 18 reveals that cities with LEED buildings were different in terms of having higher populations and higher median household incomes. Although the Kruskal-Wallis test only indicates a difference, the graphical illustrated that the cities with higher populations and median household incomes are more likely to have LEED buildings. Additionally, controlling for population in the chi-square analysis did reveal that larger cities, regardless of being suburban or rural, were more likely to have green buildings.

\section{[Insert Table 18 about here]}




\section{Instrumentation}

Respondents indicated that they never or infrequently used most of the tools listed in the survey to promote green building. As such there was no relationship between the frequency of tool use and having LEED buildings. Even though the descriptive statistics of economic-tool use reflect permitting assistance (e.g., fast tracking or expedited review), codes that require green building, publicity of green buildings (mayoral praise, ribbon cutting, general recognition), providing educational materials on green building, and partnering to conduct demonstration projects were reported to be used more frequently than most tools, there was still no relationship with their use and the increased likelihood of having LEED buildings.

In summary, cities with LEED registered or certified buildings do differ on several factors from cities that do not have LEED registered or certified buildings namely: signing climate change agreements, having guidelines and policies, being a central city, developer or architecture expertise and promotion recognizing non LEED green building. All the capacity factors were also important to green building outcomes and this held true even when considering larger cities may have fewer overall staff per 1,000 people.

Ultimately factors such as signed agreements, guidelines and policies, local developer expertise, being a central city may each be signaling a commitment to green building. This positional information can give a construction industry member a sense of certainty about the value and ongoing need for green building. Additionally having the administrative capacity to implement plans reduces transactions costs directly which will also certainly influence developers and communities to engage in green building.

\section{What are the most Salient Factors for City Professionals?}

In order to address the second research question factors analysis is employed to determine which of the factors: context, social, political, capacity and instrumentation identified in the literature are the most salient in terms of generating green buildings. Factor analysis is one method to test the validity of the concepts predicting green building. Factor analysis is a purely statistical technique that indicates the degree to which factors or items relate to a similar concept (Kim \& Mueller 1978, p. 56). In general there are two uses of factor analysis: exploratory and confirmatory. Exploratory factor analysis permits the researcher to explore if particular items are related to one another in an atheoretical fashion. For example, if an investigator did not know which personality characteristics were associated with a variety of concepts such as being introverted or extroverted, then the investigator could analyze the data using factor analysis and see which characteristics were more closely related to each other. Factor analysis is a method to test the validity of the constructs where Cronbach's Alpha helps determine the reliability measures. Typically a Cronbach's Alpha of .7 or higher demonstrates a very reliable measure of the concept. The literature and survey data analysis provided substantial information about the factors that should be related to fostering green building but which of these concepts has the most influence is not clear. Subsequently, exploratory factor analysis is employed to determine which factors for city officials will be the most salient for generating green buildings.

Table 19 provides a factor analysis of 8 motivating concepts from the literature that address issues of context that could affect transaction costs of green building and the Cronbach's Alpha for the items. Using Principal Component Analysis (PCA) as the method of extraction it is possible to see which indicators have the most weight when it comes to promoting green building. ${ }^{2}$ The factor analysis provided three factors supporting the principles drawn from the cited literature on context. Together the three factors explain 72 percent of the variance in the original items. The loadings indicate the correlation with the original 8 concepts and are used to label the three most salient factors for context from the literature.

The items loading strongly on the first factor "guidance" suggesting that city professionals rely on guidance-be it from federal, state, or a code drafting body-as some of the most influential factors. The second factor of importance is local guidance either in the form of policy goals to setting the context by having an official statement such as signing a mayor's agreement. The nearly equal loading for local guidance on the third factor coupled with the exceedingly strong loading for being a central city (as hypothesized by Lewis) taking on a regional focus suggests that location in and of itself can have significant influence on outcomes. These findings coincided with Dawkins' (2000), Saha and Paterson's (2008) theories of the relevance of positional factors. Additionally the findings support 
Lewis's (2001) views on more geographical or compositional aspects for the importance of context of central cities influence on outcomes in green building.

\section{[Insert Table 19 about here]}

Table 20 provides the factor analysis of six concepts from the literature that tap into the importance of social climate and the Cronbach's Alpha score for the items. The factor analysis provided two principal factors derived from the social climate factors. Together the two factors account for 56 percent of the variance in the original items which is nearly 22 percent lower than the context factor loadings. The loadings with the original six concepts are used to label the two salient factors for social climate the theories.

The items that loaded strongly on the first factor "Support and Implications" primarily loaded on the concept of championing ideas by local leaders, whether the leaders are in business or elected office. The implications of global warming were also associated strongly with this first factor. The high loading of support for local leaders suggests that their recognition is important for generating outcomes in green building. This supports Saha and Paterson's finding on the importance of local support or champions. The second factor "Experience" plays a clear role where green building is positively influenced by experienced developers or architects and their promotion along with examples of green building beyond LEED.

\section{[Insert Table 20 about here]}

The third factor analysis reveals which factors with regard to capacity are most important. In effort to shore up a city's capacity, features such as having a dedicated office or person to oversee this area of work, more support, or professional staff or LEED AP expertise may all foster green building. Jepson (2004), Jeong and Feiock (2006) and Sullivan (2002) all find capacity very important to outcomes. Table 21 provides the factor analysis of 4 concepts from the literature that tap into the importance of capacity and the Cronbach's Alpha score for the items. One principal factor is derived from capacity labeled here "Capacity and Expertise." This factor accounts for .39 percent of the variance in the original items which is 36 percent lower than the context factor loadings and 17 percent lower than social climate. The loadings with the original 4 concepts are highly charted indicating that a dedicated person or office, and LEED expertise are important to capacity. Support staffs, followed by the number of professional staff, were also highly related to capacity. In fact the difference was so small that all the factors loaded highly on capacity without much distinction in their importance.

\section{[Insert Table 21 about here]}

Although chi-squared analyses did not reveal an association for the political factors or economic tools, factor analysis allows an examination of the potential of political factors to affect outcomes in green building. As seen in Table 22 the factor analysis loads on two items and for the first factor, local politics, are all quite high. The second factor, competition, is driven primarily by adjacency to city with LEED buildings. The overall variance explained at 57 percent for the political factors is also greater than the capacity and nearly the same as that for the social climate factor but has considerably influence less than the context factors.

\section{[Insert Table 22 about here]}

The economic tool use was insufficiently documented by the respondents to be considered for factor analysis. However, conceptually the economic tools lined up nicely producing Cronbach's Alpha of .73, a highly reliable outcome. The fact that economic incentives were so rarely noted as being used, but often cited as the most valuable for encouraging development suggests two concerns. First, it may be that cities are offering incentives but those incentives are going unused which could indicate developers are either unaware or unfamiliar with existing incentives. Alternatively the incentives may be insufficient to encourage green building and are therefore are going unused. Second, it may be the cities are able to provide other resources such as capacity or social climate that will have longer term value to the city than one-time economic development benefits to specific developers. This may be a preferred strategy due to costs or long-term objectives. No matter what the reason, in both the survey responses and atheoretical factorial analysis we find that context and social climate are currently the stronger incentives for green building in cities in the Pacific Northwest. The survey suggests that capacity is more important for obtaining green buildings than the political factors which reportedly had no influence. However, from a completely atheorectical perspective, using factor analysis shows that political factors are demonstrated to be more tightly 
bound with green building outcomes and may have more influence than the capacity of local government offices. The differences in the match up of the chi-square analysis and factor analysis on these two points warrants additional consideration.

\section{Conclusions}

Addressing the original research questions we find that the perceptions of respondents in cities with LEED buildings are more likely to provide a context that reduces transaction costs, by being central cities, leading by example, and having some expertise and promotion in green building in their community. Cities without LEED buildings are more likely to be guessing about the importance of factors, emphasizing the importance of federal guidance, signing climate protection agreements, support of local elected leaders as having bi-modal splits with either no consequence or influence, or indicating that it has a huge impact on green building outcomes. In short, the perceptions of respondents in cities without LEED buildings over emphasized the insignificance or significance of guidance, agreement and supports when compared to cities with LEED buildings. As such, in the case of respondents from cities that have signed Climate Change Protection agreements that have LEED buildings, these cities respondents perceive that although agreements are helpful to meeting their goals, agreements in and of themselves are insufficient to reaching green building goals. Finally, the fact that central cities were so much more likely to have green buildings could be due to the fact that central cities have a greater propensity to have commercial development. This is interesting in light of the urban sprawl that communities have experienced over the last fifty years. Yet if Lewis' theory holds it may be due to their motivation to look beyond their borders and at the consequence of their action for the broader community. The fact that central cities are more outward looking has significant implications for collective action with suburban and non-metropolitan communities in dealing with climate change. However, more research is needed to draw firm conclusions on the phenomenon. Notable in light of all this is that there was no difference in green building for cities in states that did or did not have state mandates. This suggests that the most important factors prompting green building are at the local level.

Of all the factors derived from the previous research, factor analysis demonstrated that context factors which shape transaction costs are the most salient. In regard to context, being a central or core city in a metropolitan region was the very most salient factor. Local policy and local guidance ranked the next highest. Of the social climate factors, having the expertise and promotion in ones community rated the highest. In terms of capacity, having more support staff was the most important, although all the capacity factors rated high. Finally, in terms of political factors, reported influence of neighboring cities engaging in green building, political pushbacks from developers, and adjacency to city with a LEED building led the pack as the most salient from that group.

Overall four main conclusions emerge from this research. First, compositional contextual factors such as the existence of local policies and mayoral commitment through signed climate change agreements do impact green building. This signals the importance of addressing anticipated risk or transactions costs in the decision to build green. Second, positional contextual factors also play a role. One's geographical position in terms of being a central city or not was very important. Although being a central city was also noteworthy, it draws into question the importance of the capacity a city gains for green building from an angle not explored in this research. This fact, that larger cities-regardless of the city capacity of staff on a per capita basis-suggests that the market demand or the opportunity bigger cities provide, does influence green building; perhaps because they simply have more resources such as universities, or suppliers. Or alternatively, is it more about their propensity as central city to look outward? Additionally, central cities did not report being influenced by what other adjacent cities were doing in terms of green building in the same way suburbs and rural areas were. This might be a reflection of central cities outward looking propensity. Equally noteworthy though is the outcome that communities with higher median incomes, which may not be particularly large and may be more recreational in nature-such as Bend, Oregon or Ketchum, Idaho-also tend to have more green buildings. The association with income may derive from the fact it provides resilience or makes the city slightly less risk averse as a result of being more affluent. Although more research on central cities and communities with higher incomes would be needed before drawing firm conclusions.

Third, social climate was also demonstrated to provide salient factors for achieving green building. However, caution should be used in extracting too much from this finding. This is because several of these factors are derived from the respondents' perceptions rather than explicit measurable data on the concept such as number times a mayor praised green buildings. Nonetheless, these data do suggest that respondents who perceive their cities as 
demonstrating leadership in green building, are supportive of efforts to build green, and promote the experience of other successful people and projects can foster green building in their communities.

Fourth, the survey data suggest that neither political nor economic tools are currently driving green building. In the case of political factors these items may rival the contribution of a local planning department's capacity. Furthermore, factor analysis revealed adjacency to a city with LEED registered or certified buildings did indeed influence non central cities in having LEED buildings. One theory is that LEED building construction is driven by competition. However, another theory, one not tested here, is that local resources, in an adjacent city, in terms of knowledge or skills or materials may be fostering neighboring communities to engage in green building.

The most promising practices for cities all support finding ways to reduce transaction costs. Factors such as setting the tone or expectations through policies and guidelines, having the local expertise and support to make the outcome occur are important for reducing uncertainty and in turn transaction costs. Even negative factors such as political pushback to maintain the status quo potentially stem from sunk cost associated with doing business the same way, or anticipated costs in learning new ways to build and using new suppliers. It may even be that having examples in adjoining communities drives competition for more green buildings thus increasing demand or reducing costs by having area expertise.

Cities that take the lead and provide support for green building will more likely achieve their green building outcomes than those that wait for mandates or higher level guidance. More research on why central cities are more likely to engage in green building is clearly needed. Future research should also consider the development rates as a control or competing explanation in green building outcomes in cities. Although green building is most certainly warranted in central cites where there is a preponderance of commercial buildings, the collective action issues related to climate change should spur us to find out more about why central cities are more likely to build green. Additional research on the political factors and economic tools is also needed. Although this study raises many questions about outcomes it does provide perceptions, empirical evidence, and findings that point to promising practices cities can tap into to achieve more green building. An in-depth look at just a few cases would certainly go a long way toward helping public administrators better understand how some of these factors play out with regard to green building outcomes. 


\section{References}

Allen, J. H. \& Potiowsky, T. (2008). Portland's Green Building cluster: Economic Trends and Impacts. Economic Development Quarterly 22(4), 303-315.

Author and Co-Author. 2010. Forthcoming. Tax Increment Financing in Missouri: An Analysis of Determinants, Competitive Dynamics, Equity and Path Dependency. Economic Development Quarterly.

Basolo, V. (2000). City Spending on Economic Development versus Affordable Housing: Does Inter-city Competition or Local Politics Drive Decisions? Journal of Urban Affairs. 22(3), 317-332.

Chao, M. Parker,G. Mahon, D. \& Kammerud, R. (1999). Recognition of Energy Costs and Energy Performance in Commercial Property Valuation: Recommendations and Guidelines for Appraisers, February 1999. For the Pacific Gas \& Electric Company and the U.S. Environmental Protection Agency. Retrieved June 29, 2009, from http://www.imt.org/ PDF\%20files/CA\%20RGs\%202-99.PDF

Dawkins, C, J. (2000). Transactions Cost and the Land Use Planning Process. Journal of Planning Literature 14(4), 507-518.

Duerksen, C. (2009). Saving the World through Zoning: Sustainable Community Development Code Reform Project. Presented at the Planning in the West conference, Boise, Idaho, June 17-18, 2009.

Energy Information Administration (2009). Retrieved June 22, 2009, from http://www.eia.doe. gov/oiaf/1605/ggrpt/index.html

Eisinger, P. K. (1988). The Rise of the Entrepreneurial State. Madison: University of Wisconsin Press.

Feiock, R. C. \& Stream, C. (2001). Environmental Protection Versus Economic Development: A False Trade-Off? Public Administration Review 61(3), 313-321.

Interviews (2009). Conducted by author February - March 2009.

Jacobs, J.. (1960). The Economy of Cities. New York: Random House

Jeong, M.G. \& Feiock, R. (2006). Impact Fees, Growth Management, and Development A contractual Approach to Local Policy and Governance. Urban Affairs Review. 41(6), 749-768.

Jepson, Jr. E. J. (2004). The Adoption of Sustainable Development Policies and Techniques in U.S. Cities: How Wide, How Deep, and What Role for Planners? Journal of Planning Education and Research. 23, 229241.

Kim, J. \& Mueller, C.W. (1978). Introduction to Factor Analysis: What it is and How to do it. Newbury Park: Sage.

Lewis, P.G. (2001). Looking Outward or Turning Inward? Motivations for Development Decisions in California Central Cities and Suburbs. Urban Affairs Review. 36(5), 696-720.

Linder, S.H. \& Peters, B.G. (1989). Instruments of Government: Perceptions and Contexts. Journal of Public Policy. 9(1), 35-58.

Lockwood, C. (2008). The dollars and sense of Green Retrofits. Joint study by Deloitte and Charles Lockwood. Retrieved December 8, 2009 from http://www.deloitte.com/assests/ DcomUnitedStates/Local\%20Assests/Documents?us_re_Dollars_Sense_Retrofits_ 190608_.pdf. 
McGuire, M. (2000). Collaborative Policy Making and Administration: The Operational Demands of Local Economic Development. Economic Development Quarterly. 14(3), 278-291

Peterson, P.E. (1981). City Limits. Chicago: University of Chicago Press.

Porter, M. (1990). The Competitive Advantage of Nations. Harvard Business Review. 68(2), 77-93.

Saha, D. \& Paterson, R.G. (2008). Local Government Efforts to Promote the "Three E's" of Sustainable Development: Survey in Medium to Large Cities in the United States. Journal of Planning Education and Research 28, 21-37.

Smith, A. (2003). Building Momentum: National Trends and Prospects for High-Performance Green Buildings. Report by the U.S. Green Building Council for the U.S. Senate Committee on Environment and Public Works, USGBC, Washington, D.C.

Stone, C. (1989). Regime politics: governing Atlanta, 1946-1988. Lawrence: University Press of Kansas.

Sullivan, D.M. (2002). Local Governments as Risk Takers and Risk Reducers: An Examination of Business Subsidies and Subsidy Controls. Economic Development Quarterly. 16(2), 115-126.

United States Green Building Council. (2008). Buildings and Climate Change. Retrieved March 7, 2010, from http://www.documents.dgs.ca.gov/dgs/pio/facts/LA\% 20workshop/climate.pdf .

United States Conference of Mayor's Climate Protection Agreement. 2010. Retrieved April 15, 2010, from http://www.usmayors.org/climateprotection/revised/.

Waston, R. (2008). Green Building Impact Report 2008. Retrieved December 8, 2009 from http://www.greenbix.com/research/report/2008/11/18/green-building-impact-report-2008.

Wildavsky, A. (1964). Leadership in a small town. Totawa, NJ: Bedminster Press.

Zahran, S., Grover, H. Brody, S. D. and Vedlitz, A. (2008). Risk, Stress, and Capacity: Explaining Metropolitan Commitment to Climate Protection. Urban Affairs Review. 
Table 1: Classification of Green Building Economic Policy Instruments

\begin{tabular}{|c|c|c|c|}
\hline Promotion & Subsidy & Direct Provision & Contracting \\
\hline $\begin{array}{l}\text { Provide financial } \\
\text { awards for green } \\
\text { building }\end{array}$ & $\begin{array}{l}\text { Financial reward for } \\
\text { LEED certification }\end{array}$ & $\begin{array}{l}\text { Partner to conduct } \\
\text { demonstration projects }\end{array}$ & $\begin{array}{l}\text { Permitting assistance } \\
\text { (e.g. fast-tracking or } \\
\text { expedited review) }\end{array}$ \\
\hline $\begin{array}{l}\text { Provide educational } \\
\text { materials }\end{array}$ & $\begin{array}{l}\text { Tax increment } \\
\text { financing }\end{array}$ & $\begin{array}{l}\text { Infrastructure } \\
\text { improvement (e.g., } \\
\text { sewer or water) }\end{array}$ & $\begin{array}{l}\text { Zoning (e.g., } \\
\text { increased Floor Area } \\
\text { Ratio for buildings } \\
\text { that meet or exceed } \\
\text { specific green } \\
\text { building standards) }\end{array}$ \\
\hline $\begin{array}{l}\text { Provide training on } \\
\text { green building } \\
\text { technology }\end{array}$ & $\begin{array}{l}\text { Low cost loans - by } \\
\text { covering a portion of } \\
\text { the loan at } \\
\text { substantially reduced } \\
\text { rate }\end{array}$ & & $\begin{array}{l}\text { Codes that require } \\
\text { specific green } \\
\text { building standards }\end{array}$ \\
\hline \multirow{2}{*}{$\begin{array}{l}\text { Publicity for green } \\
\text { buildings in the form of } \\
\text { mayoral praise, ribbon } \\
\text { cutting, and general } \\
\text { recognition }\end{array}$} & $\begin{array}{l}\text { Low cost loans }- \text { by } \\
\text { paying some of the } \\
\text { interest }\end{array}$ & & \\
\hline & $\begin{array}{l}\text { Grants } \\
\text { Tax credits } \\
\text { Fee reduction -for } \\
\text { buildings that meet or } \\
\text { exceed specified } \\
\text { green standards }\end{array}$ & & \\
\hline
\end{tabular}


Table 2: Independent Variables in the Models

\begin{tabular}{|c|c|c|c|c|}
\hline Context & Social Climate & Political & Capacity & Instrumentation \\
\hline $\begin{array}{l}\text { Signed climate } \\
\text { agreement }\end{array}$ & $\begin{array}{l}\text { Mayor supports } \\
\text { green building }\end{array}$ & $\begin{array}{l}\text { The influence of } \\
\text { other } \\
\text { neighboring } \\
\text { cities engaging in } \\
\text { green building }\end{array}$ & $\begin{array}{l}\text { Lead office or } \\
\text { personnel } \\
\text { responsible for } \\
\text { green building } \\
\text { projects or activities } \\
\text { in the city }\end{array}$ & Promotion \\
\hline $\begin{array}{l}\text { Local green } \\
\text { building policy }\end{array}$ & $\begin{array}{l}\text { Architect or } \\
\text { developer familiar } \\
\text { with green building }\end{array}$ & $\begin{array}{l}\text { The influence of } \\
\text { other } \\
\text { neighboring } \\
\text { cities not } \\
\text { engaging in } \\
\text { green buildings }\end{array}$ & $\begin{array}{l}\text { Number of public } \\
\text { works or planners } \\
\text { working specifically } \\
\text { for the city }\end{array}$ & Subsidy \\
\hline $\begin{array}{l}\text { Local green } \\
\text { building guidelines }\end{array}$ & $\begin{array}{l}\text { Other buildings } \\
\text { recognized as green } \\
\text { that are not LEED } \\
\text { certified }\end{array}$ & $\begin{array}{l}\text { Influence of } \\
\text { developer } \\
\text { pushback (threat } \\
\text { that they will } \\
\text { take development } \\
\text { elsewhere to } \\
\text { avoid new } \\
\text { standards) }\end{array}$ & $\begin{array}{l}\text { Number of support } \\
\text { staff that work for } \\
\text { the public works } \\
\text { personnel or } \\
\text { planners that work } \\
\text { for the city }\end{array}$ & Direct Provision \\
\hline $\begin{array}{l}\text { State has a policy } \\
\text { on green building }\end{array}$ & $\begin{array}{l}\text { Implications of } \\
\text { green building on } \\
\text { global warming }\end{array}$ & $\begin{array}{l}\text { Influence of } \\
\text { political } \\
\text { pushback from } \\
\text { developers } \\
\text { (encouraging } \\
\text { leaders not to } \\
\text { adopt new } \\
\text { standards) }\end{array}$ & $\begin{array}{l}\text { Number of staff that } \\
\text { are LEED AP }\end{array}$ & Contracting \\
\hline $\begin{array}{l}\text { Federal guidance is } \\
\text { seen as having an } \\
\text { influence }\end{array}$ & $\begin{array}{l}\text { Championing of } \\
\text { green buildings by } \\
\text { local business } \\
\text { leaders }\end{array}$ & & & \\
\hline $\begin{array}{l}\text { State guidance is } \\
\text { seen has having a } \\
\text { influence } \\
\text { International Code } \\
\text { Council or other } \\
\text { drafting body seen } \\
\text { has having an } \\
\text { influence } \\
\text { Cities for Climate } \\
\text { Protection Mayor's } \\
\text { agreement seen as } \\
\text { having an influence } \\
\text { Central city, } \\
\text { Suburban or } \\
\text { Nonmetropolitan }\end{array}$ & $\begin{array}{l}\text { The support of green } \\
\text { building by local } \\
\text { elected officials }\end{array}$ & & & \\
\hline
\end{tabular}


Table 3: Comparison of responding and nonresponding cities.

\begin{tabular}{crrrrr}
\hline Cities & $\begin{array}{c}\text { Population } \\
2000\end{array}$ & $\begin{array}{l}\text { Percentage } \\
\text { Change in } \\
\text { Population } \\
(1990-2000)\end{array}$ & $\begin{array}{c}\text { Percent with } \\
\text { a Bachelor's } \\
\text { Degree or } \\
\text { higher }\end{array}$ & $\begin{array}{c}\text { Median } \\
\text { household } \\
\text { income } \\
(1999)\end{array}$ & $\begin{array}{c}\text { Poverty Rate } \\
\text { Percentage } \\
(1999)\end{array}$ \\
\hline $\begin{array}{c}\text { Responding } \\
\text { Cities }\end{array}$ & 22,784 & $47.3 \%$ & $23.9 \%$ & 43,050 & $10.9 \%$ \\
$\begin{array}{c}\text { Nonresponding } \\
\text { cities }\end{array}$ & 21,013 & $49.8 \%$ & $20.9 \%$ & 42,795 & $11.3 \%$ \\
$\begin{array}{c}\text { Cities Average } \\
\text { K-W Test }\end{array}$ & 21,885 & $48.5 \%$ & $22.4 \%$ & 42,925 & $11.1 \%$ \\
\hline
\end{tabular}

a The Kruskal-Wallis test for the null hypothesis of probability of equality of population responding and nonresponding cities

Table 4: Chi-square Analysis Mayor having signed Climate Change Agreement and having LEED buildings

\begin{tabular}{l|rrr}
\hline & \multicolumn{3}{|l}{ Mayor is signatory on Climate } \\
& Change Agreement? \\
\hline LEED & No & \multicolumn{3}{c}{ Yes } & Total \\
Buildings & \multicolumn{3}{c}{$58 \%$} \\
No & $65 \%$ & $14 \%$ & $(229)$ \\
& & & $42 \%$ \\
Yes & $35 \%$ & $86 \%$ & $(163)$ \\
& & & $100 \%$ \\
Total & $100 \%$ & $100 \%$ & $(392)$ \\
\hline
\end{tabular}

$\chi^{2}=48.21, \quad \operatorname{Pr}=.00 ;$ Crammer's V $=.35$

Table 5: Chi-square analysis of green building goal or priority and having LEED buildings

\begin{tabular}{|c|c|c|c|c|}
\hline & \multicolumn{4}{|c|}{$\begin{array}{l}\text { Has your city established green building as a } \\
\text { goal or priority? }\end{array}$} \\
\hline $\begin{array}{l}\text { LEED } \\
\text { Buildings }\end{array}$ & No & $\begin{array}{l}\text { Yes } \\
\text { informal/ } \\
\text { unwritten }\end{array}$ & $\begin{array}{l}\text { Yes } \\
\text { Formal/ } \\
\text { written }\end{array}$ & Total \\
\hline No & $73 \%$ & $39 \%$ & $28 \%$ & $\begin{array}{r}57 \% \\
(112)\end{array}$ \\
\hline Yes & $27 \%$ & $61 \%$ & $72 \%$ & $\begin{array}{l}84 \% \\
\text { (43) }\end{array}$ \\
\hline Total & $\begin{array}{l}100 \% \\
(112)\end{array}$ & $\begin{array}{r}100 \% \\
(59)\end{array}$ & $\begin{array}{r}100 \% \\
(25)\end{array}$ & $\begin{array}{l}100 \% \\
(196)\end{array}$ \\
\hline
\end{tabular}

$\chi^{2}=28.42, \quad \operatorname{Pr}=0.00$, Crammer's $V=.38$ 
Table 6: Chi-square analysis of green building policies or guidelines and having LEED buildings

\begin{tabular}{|c|c|c|c|c|}
\hline & \multicolumn{4}{|c|}{$\begin{array}{l}\text { Has your city established green building as a } \\
\text { goal or priority? }\end{array}$} \\
\hline $\begin{array}{l}\text { LEED } \\
\text { Buildings }\end{array}$ & No & $\begin{array}{l}\text { Yes } \\
\text { informal/ } \\
\text { unwritten }\end{array}$ & $\begin{array}{l}\text { Yes } \\
\text { Formal/ } \\
\text { written }\end{array}$ & Total \\
\hline No & $64 \%$ & $36 \%$ & $33 \%$ & $\begin{array}{r}57 \% \\
(112)\end{array}$ \\
\hline Yes & $35 \%$ & $64 \%$ & $67 \%$ & $\begin{array}{l}43 \% \\
(84) \\
\end{array}$ \\
\hline Total & $\begin{array}{l}100 \% \\
(147)\end{array}$ & $\begin{array}{r}100 \% \\
(25)\end{array}$ & $\begin{array}{r}100 \% \\
(24)\end{array}$ & $\begin{array}{r}100 \% \\
(196)\end{array}$ \\
\hline
\end{tabular}

$\chi^{2}=13.48, \operatorname{Pr}=0.00$, Crammer's V=.26

Table 7: Chi-square analysis on influence of Federal guidance on green buildings and a city having LEED buildings

\begin{tabular}{l|rrrrrr}
\hline LEED & 1 & 2 & 3 & 4 & 5 & Total \\
Buildings & $\begin{array}{c}\text { No } \\
\text { Influence }\end{array}$ & & & & \multicolumn{3}{c}{$\begin{array}{c}\text { Strong } \\
\text { Influence }\end{array}$} \\
No & $68 \%$ & $40 \%$ & $58 \%$ & $44 \%$ & $71 \%$ & $54 \%$ \\
Yes & $32 \%$ & $60 \%$ & $42 \%$ & $56 \%$ & $29 \%$ & $\begin{array}{r}45 \% \\
\end{array}$ \\
\hline Total & $100 \%$ & $100 \%$ & $100 \%$ & $100 \%$ & $100 \%$ & $100 \%$ \\
& $(34)$ & $(50)$ & $(53)$ & $(25)$ & $(24)$ & $(186)$ \\
\hline
\end{tabular}

$\chi^{2}=10.65, \quad \operatorname{Pr}=0.03 ;$ Crammer's V $=.24$

Table 8: Chi-square analysis on influence of Cities for Climate Protection agreement a city having LEED buildings

\begin{tabular}{l|rrrrrr}
\hline LEED & 1 & 2 & 3 & 4 & 5 & Total \\
Buildings & $\begin{array}{c}\text { No } \\
\text { Influence }\end{array}$ & & & & \multicolumn{3}{c}{$\begin{array}{c}\text { Very } \\
\text { Strong }\end{array}$} \\
No & $63 \%$ & $35 \%$ & $63 \%$ & $33 \%$ & $56 \%$ & $55 \%$ \\
& & & & & & \\
Yes & $37 \%$ & $65 \%$ & $37 \%$ & $67 \%$ & $44 \%$ & $45 \%$ \\
& & & & & & $(78)$ \\
\hline Total & $100 \%$ & $100 \%$ & $100 \%$ & $100 \%$ & $100 \%$ & $100 \%$ \\
& $(67)$ & $(26)$ & $(30)$ & $(15)$ & $(34)$ & $(172)$ \\
\hline
\end{tabular}

$\chi^{2}=9.64, \quad \operatorname{Pr}=0.05 ;$ Crammer's V=.24 
Table 9: Chi-square analysis of City, Suburb, or Nonmetropolitan city on having LEED buildings

\begin{tabular}{|c|c|c|c|c|}
\hline $\begin{array}{l}\text { LEED } \\
\text { Buildings }\end{array}$ & Core City & $\begin{array}{l}\text { Suburban } \\
\text { City }\end{array}$ & $\begin{array}{l}\text { Non } \\
\text { Metropolitan } \\
\text { City }\end{array}$ & Total \\
\hline No & $8 \%$ & $58 \%$ & $70 \%$ & $\begin{array}{r}59 \% \\
(232)\end{array}$ \\
\hline Yes & $92 \%$ & $42 \%$ & $30 \%$ & $\begin{array}{r}41 \% \\
(164) \\
\end{array}$ \\
\hline Total & $\begin{array}{r}100 \% \\
(25)\end{array}$ & $\begin{array}{l}100 \% \\
(239)\end{array}$ & $\begin{array}{l}100 \% \\
(132)\end{array}$ & $\begin{array}{r}100 \% \\
(395)\end{array}$ \\
\hline
\end{tabular}

$\chi^{2}=33.15, \quad \operatorname{Pr}=0.00$, Crammer's $\mathrm{V}=.29$

Table 10: Chi-square analysis Developer or Architect familiar with and promotes green building on having LEED buildings

\begin{tabular}{|c|c|c|c|}
\hline & \multicolumn{3}{|c|}{$\begin{array}{l}\text { Developer or Architect that is familiar } \\
\text { with and promotes green building? }\end{array}$} \\
\hline $\begin{array}{l}\text { LEED } \\
\text { Buildings }\end{array}$ & No & Yes & Total \\
\hline No & $78 \%$ & $41 \%$ & $\begin{array}{l}51 \% \\
(75)\end{array}$ \\
\hline Yes & $22 \%$ & $59 \%$ & $\begin{array}{r}48 \% \\
(72)\end{array}$ \\
\hline Total & $\begin{array}{r}100 \% \\
(41)\end{array}$ & $\begin{array}{l}100 \% \\
(106)\end{array}$ & $\begin{array}{l}100 \% \\
(147)\end{array}$ \\
\hline
\end{tabular}

$\chi^{2}=16.62, \quad \operatorname{Pr}=.00 ;$ Crammer's V $=.33$

Table 11: Chi-square analysis Other formally recognized non LEED Green buildings and having LEED buildings

\begin{tabular}{|c|c|c|c|}
\hline & \multicolumn{3}{|c|}{$\begin{array}{l}\text { Other buildings that formally } \\
\text { recognized as green buildings that are } \\
\text { not LEED Certified (e.g, Earth } \\
\text { Advantage, EnergyStar, NetZero) in } \\
\text { your city? }\end{array}$} \\
\hline LEED & No & Yes & Total \\
\hline $\begin{array}{l}\text { Buildings } \\
\text { No }\end{array}$ & $72 \%$ & $34 \%$ & $\begin{array}{r}56 \% \\
(83)\end{array}$ \\
\hline Yes & $28 \%$ & $66 \%$ & $\begin{array}{r}44 \% \\
(65)\end{array}$ \\
\hline Total & $\begin{array}{r}100 \% \\
(86)\end{array}$ & $\begin{array}{r}100 \% \\
(62)\end{array}$ & $\begin{array}{l}100 \% \\
(148)\end{array}$ \\
\hline
\end{tabular}

$\chi^{2}=21.37, \operatorname{Pr}=.00 ;$ Crammer's $\mathrm{V}=.38$ 
Table 12: Chi-square analysis on influence of support for Green Building by Local Elected Official and a city having LEED buildings

\begin{tabular}{|c|c|c|c|c|c|c|}
\hline $\begin{array}{l}\text { LEED } \\
\text { Buildings }\end{array}$ & $\begin{array}{c}1 \\
\text { No } \\
\text { Influence }\end{array}$ & 2 & 3 & 4 & $\begin{array}{c}5 \\
\text { Very } \\
\text { Strong } \\
\text { Influence }\end{array}$ & Total \\
\hline No & $85 \%$ & $56 \%$ & $50 \%$ & $41 \%$ & $61 \%$ & $\begin{array}{r}55 \% \\
(102)\end{array}$ \\
\hline Yes & $15 \%$ & $44 \%$ & $50 \%$ & $59 \%$ & $39 \%$ & $\begin{array}{r}45 \% \\
(84)\end{array}$ \\
\hline Total & $\begin{array}{r}100 \% \\
(13) \\
\end{array}$ & $\begin{array}{r}100 \% \\
(16) \\
\end{array}$ & $\begin{array}{r}100 \% \\
(42) \\
\end{array}$ & $\begin{array}{r}100 \% \\
(44) \\
\end{array}$ & $\begin{array}{r}100 \% \\
(71) \\
\end{array}$ & $\begin{array}{l}100 \% \\
(186)\end{array}$ \\
\hline
\end{tabular}

$\chi^{2}=9.45, \quad \operatorname{Pr}=0.05 ;$ Crammer's V=.23

Table 13: Chi-square analysis of City being Adjacent to a City with green building and having LEED buildings

\begin{tabular}{|c|c|c|c|c|}
\hline & $\begin{array}{l}\text { Adjacent } \mathrm{t} \\
\text { Buildings? }\end{array}$ & a City with & Green & \\
\hline $\begin{array}{l}\text { LEED } \\
\text { Buildings }\end{array}$ & No & Yes & Total & \\
\hline No & $72 \%$ & $1 \%$ & & $\begin{array}{r}56 \% \\
(232)\end{array}$ \\
\hline Yes & $28 \%$ & $99 \%$ & & $\begin{array}{r}41 \% \\
(164)\end{array}$ \\
\hline Total & $\begin{array}{l}100 \% \\
(319)\end{array}$ & $\begin{array}{r}100 \% \\
(77)\end{array}$ & & $\begin{array}{l}100 \% \\
(396)\end{array}$ \\
\hline
\end{tabular}

$\chi^{2}=129.29, \quad \operatorname{Pr}=.00 ;$ Crammer's $\mathrm{V}=.57$

Table 14: Chi-square analysis of Lead office or personnel responsible for green building and having LEED buildings

\begin{tabular}{|c|c|c|c|}
\hline \multirow{3}{*}{$\begin{array}{l}\text { LEED } \\
\text { Buildings } \\
\text { No }\end{array}$} & \multicolumn{3}{|c|}{$\begin{array}{l}\text { Is there a lead office or personnel } \\
\text { responsible for green building } \\
\text { projects in your city? }\end{array}$} \\
\hline & No & Yes & Total \\
\hline & $64 \%$ & $36 \%$ & $\begin{array}{r}58 \% \\
(115)\end{array}$ \\
\hline Yes & $36 \%$ & $64 \%$ & $\begin{array}{r}42 \% \\
(83)\end{array}$ \\
\hline Total & $\begin{array}{l}100 \% \\
(159)\end{array}$ & $\begin{array}{r}100 \% \\
(39)\end{array}$ & $\begin{array}{l}100 \% \\
(198)\end{array}$ \\
\hline
\end{tabular}


Table 15: Chi-square analysis number of public works personnel or planners working for the city on having LEED buildings

\begin{tabular}{l|rrrrr}
\hline & \multicolumn{5}{l}{ Number of public works personnel or planners } \\
\hline LEED & 0 & $1-3$ & $4-6$ & 7 or more & Total \\
Buildings & & \multicolumn{5}{c}{4} & & & \\
No & $\mathrm{n} / \mathrm{a}$ & $70 \%$ & $69 \%$ & $47 \%$ & $50 \%$ \\
& & & & & $(114)$ \\
Yes & $\mathrm{n} / \mathrm{a}$ & $30 \%$ & $31 \%$ & $53 \%$ & $50 \%$ \\
& & & & & $(82)$ \\
\hline Total & & $100 \%$ & $100 \%$ & $100 \%$ & $100 \%$ \\
& $(0)$ & $(57)$ & $(39)$ & $(100)$ & $(196)$ \\
\hline
\end{tabular}

$\chi^{2}=10.46, \quad \operatorname{Pr}=0.00 ;$ Crammer's V=.23

Table 16: Chi-square analysis of number of support staff for public works personnel and planners on having LEED buildings

\begin{tabular}{l|rrrrr}
\hline & \multicolumn{7}{l}{ Number of support staff } \\
\hline $\begin{array}{l}\text { LEED } \\
\text { Buildings }\end{array}$ & 0 & $1-3$ & $4-6$ & 7 or more & Total \\
No & $63 \%$ & $67 \%$ & $52 \%$ & $25 \%$ & $57 \%$ \\
& & & & & $(103)$ \\
Yes & $36 \%$ & $33 \%$ & $48 \%$ & $75 \%$ & $43 \%$ \\
& & & & & $(78)$ \\
\hline Total & $100 \%$ & $100 \%$ & $100 \%$ & $100 \%$ & $100 \%$ \\
& $(11)$ & $(109)$ & $(29)$ & $(32)$ & $(181)$ \\
\hline
\end{tabular}

$\chi^{2}=18.31, \quad \operatorname{Pr}=.00 ;$ Crammer's V=.32

Table 17: Chi-square analysis having staff that are LEED AP on having LEED buildings

\begin{tabular}{|c|c|c|c|}
\hline & \multicolumn{3}{|c|}{$\begin{array}{l}\text { How many staff in your city are } \\
\text { accredited as a LEED AP? }\end{array}$} \\
\hline $\begin{array}{l}\text { LEED } \\
\text { Buildings }\end{array}$ & No Staff & $\begin{array}{l}\text { One or } \\
\text { more staf } \\
\text { person }\end{array}$ & \\
\hline No & $60 \%$ & $21 \%$ & $\begin{array}{l}53 \% \\
(54)\end{array}$ \\
\hline Yes & $40 \%$ & $79 \%$ & $\begin{array}{l}47 \% \\
(48)\end{array}$ \\
\hline Total & $\begin{array}{l}100 \% \\
(83)\end{array}$ & $\begin{array}{l}100 \% \\
(19)\end{array}$ & $\begin{array}{l}100 \% \\
(102)\end{array}$ \\
\hline
\end{tabular}

$\chi^{2}=9.53, \quad \operatorname{Pr}=0.002, \mathrm{~V}=.31$ 
Table 18 : Comparison of Cities with and without LEED Buildings.

\begin{tabular}{|c|c|c|c|c|}
\hline $\begin{array}{c}\text { LEED } \\
\text { Buildings }\end{array}$ & $\begin{array}{c}\text { Population } \\
2000\end{array}$ & $\begin{array}{l}\text { Percentage } \\
\text { Change in } \\
\text { Population } \\
(1990-2000)\end{array}$ & $\begin{array}{c}\text { Median } \\
\text { household } \\
\text { income } \\
(1999)\end{array}$ & $\begin{array}{c}\text { Poverty Rate } \\
\text { Percentage } \\
\text { (1999) }\end{array}$ \\
\hline Yes & 38,083 & $51 \% \%$ & 44,852 & $11 \%$ \\
\hline No & 10,456 & $47 \%$ & 41,565 & $11 \%$ \\
\hline Average & 21,885 & $48.5 \%$ & 42,925 & $11 \%$ \\
\hline $\mathrm{K}-\mathrm{W}$ Test ${ }^{\mathrm{a}}$ & .00 & .17 & .00 & .95 \\
\hline
\end{tabular}

a The Kruskal-Wallis test for the null hypothesis of probability of equality of cities with and without LEED buildings

Table 19: Factor Analysis of 8 Context Concepts on Green Building

\begin{tabular}{lrrr}
\hline Concepts & \multicolumn{3}{c}{ Factors } \\
& Guidance & \multicolumn{1}{l}{$\begin{array}{l}\text { Local } \\
\text { Policy }\end{array}$} \\
Signed Climate Change & & & \\
Protection (CCP) & .23 & .45 & .39 \\
Agreement & & & .31 \\
Local Policy & .28 & .51 & .41 \\
Local Guidelines & .24 & & \\
Federal Guidance & .46 & .33 & .11 \\
& .49 & .28 & .06 \\
State Guidance & & & .04 \\
ICC or drafting body & .42 & .22 & .04 \\
& .41 & .22 & .71 \\
CCP agreement & .09 & .22 & \\
Central City & .75 & & 1.2 \\
Cronbach's $\alpha$ & 2.7 & 1.9 & 14.88 \\
Eigenvalues & 33.56 & 23.64 & \\
Percent of Total & & & \\
Variance & 72.08 & & \\
Total Explained & & & \\
Variance = & & & \\
\hline
\end{tabular}

Note: Entries are factor coefficients from a principal component analysis with orthogonal rotation. $\mathrm{n}=160$ 
Table 20: Factor Analysis of 6 Social Climate Concepts on Green Building

\begin{tabular}{lrr}
\hline Concepts & \multicolumn{2}{c}{ Factors } \\
& $\begin{array}{c}\text { Support and } \\
\text { Implications }\end{array}$ & Experience \\
Mayoral support & .23 & .09 \\
Architect or developer familiar & .17 & .67 \\
with and promotes green & & \\
building & .23 & .66 \\
Green Buildings other LEED in & & \\
community & .46 & .15 \\
Implications of green building & & .18 \\
on global warming & .55 & .21 \\
Business leaders champion & & \\
green building & .59 & \\
Local elected official support & & \\
green building & .57 & \\
Cronbach's $\alpha$ & 1.9 & \\
Eigenvalues & 32.39 & \\
Percent of Total Variance & 55.83 & \\
Total Explained Variance $=$ & & \\
\hline
\end{tabular}

Note: Entries are factor coefficients from a principal component analysis with orthogonal rotation. $\mathrm{n}=97$

Table 21: Factor Analysis of 4 Capacity Concepts for Green Building

\begin{tabular}{lr}
\hline Concepts & Factor \\
\hline & $\begin{array}{r}\text { Capacity } \\
\text { and } \\
\text { Expertise }\end{array}$ \\
Lead office or personnel & .51 \\
Number of public works or planning & .48 \\
professional working for city & \\
Number of support staff for public works & .58 \\
or planning professionals & \\
Number of staff that are LEED AP & .41 \\
Cronbach's $\alpha$ & .51 \\
Eigenvalues & 1.6 \\
Percent of Total Variance & 38.93 \\
Total Explained Variance $=$ & 38.93 \\
\hline
\end{tabular}

Note: Entries are factor coefficients from a principal component analysis with orthogonal rotation. $\mathrm{n}=167$ 
Table 22: Factor Analysis of 4 Political Concepts for Green Building

\begin{tabular}{lrr}
\hline Concepts & \multicolumn{2}{c}{ Factors } \\
\hline & $\begin{array}{r}\text { Local } \\
\text { Politics }\end{array}$ & Competition \\
Other neighboring cities engaging in green & .54 & -.18 \\
building & .41 & .59 \\
$\begin{array}{l}\text { Other neighboring cities not engaging in green } \\
\text { building }\end{array}$ & .49 & -.15 \\
Developer pushback (threat that they will take & & \\
development elsewhere to avoid new & & \\
standards) & .54 & .05 \\
Political pushback from developers & & \\
(encouraging leaders not to adopt new & & .77 \\
standards) & -.12 & \\
Adjacent to a city with LEED building & .67 & 1.93 \\
Cronbach's $\alpha$ & 1.66 & 23.88 \\
Eigenvalues & 33.22 & \\
Percent of Total Variance & 57.09 & \\
Total Explained Variance $=$ & & \\
\hline
\end{tabular}

Note: Entries are factor coefficients from a principal component analysis with orthogonal rotation. $\mathrm{n}=55$

\footnotetext{
${ }^{1}$ An MSA is characterized as having a central core city, comprising an urbanized area of at least 50,000 people, together with adjacent counties that have social and economic connectivity with a larger central core. The boundary designation of an MSA is determined by the Office of Management and Budget (OMB). The core city in this study is the central core city as defined by the MSA designation.

${ }^{2}$ A preliminary analysis using the Keiser-Meyer-Olkin (KMO) reveals sampling adequacy. The measure indicated that all of the data except economic tools are suitable for PCA. The sampling adequacy exceeds the critical value of .5 where the KMO equals .65 for the context concepts, .58 for the social climate factors, .60 political factors, .58 for capacity but not for the economic tool concepts at .44 .
} 